\title{
The effect of cost information on buyer-supplier negotiations in different power settings
}

\author{
Alexandra Van den Abbeele ${ }^{\mathrm{a}, *}$, Filip Roodhooft ${ }^{\mathrm{a}, \mathrm{b}}$, Luk Warlop ${ }^{\mathrm{a}}$ \\ ${ }^{a}$ Katholieke Universiteit Leuven, Naamsestraat 69, 3000 Leuven, Belgium \\ ${ }^{\mathrm{b}}$ Vlerick Leuven Gent Management School, Naamsestraat 69, 3000 Leuven, Belgium
}

\begin{abstract}
We investigate the influence of total cost of ownership (TCO) information on buyer-supplier negotiations in different power settings. Based on social exchange theory and recent literature on information processing, we expect that buyers with detailed TCO information and less power than their negotiation partners may try to (re)gain control over their own outcomes by sharing information. The results of our experiment indicate that the performance disadvantage of less powerful buyers is less pronounced when the buyer has detailed TCO information, whereas more powerful buyers do not seem to be able to profit from TCO information. These somewhat counterintuitive findings are explained through detailed analysis of the buyer's negotiation behavior, which shows that less powerful buyers who have access to TCO data use problem solving techniques more frequently than powerful buyers, who tend to rely on distributive bargaining techniques instead. We conclude that power can motivate a failure to share TCO information, resulting in less effective interfirm negotiation outcomes.
\end{abstract}

(c) 2008 Published by Elsevier Ltd.

\section{Introduction}

This study investigates whether buyers benefit from total cost of ownership (TCO) information when negotiating with suppliers across different power settings. TCO can be seen as an application of activity-based costing (ABC) to an interfirm context (Wouters, Anderson, \& Wynstra, 2005). It quantifies the costs of the activities involved in

\footnotetext{
* Corresponding author. Tel.: +32 163269 36; fax: +32 1632 6732.

E-mail addresses: alexandra.vandenabbeele@econ. kuleuven.be (A. Van den Abbeele), filip.roodhooft@econ. kuleuven.be (F. Roodhooft), luk.warlop@econ.kuleuven.be (L. Warlop).
}

acquiring and using purchased goods or services. As interfirm relations have become increasingly important and as purchasing professionals in many companies still need to demonstrate the contribution they make to their firm, it is relevant for buyers to identify the management accounting tools that might contribute to their market success and profitability. TCO is a tool that supports purchasing decisions by focusing on all costs related to a purchase rather than simply on price (Ellram, 1995). Prior literature suggests that TCO information can improve interfirm cooperation, as a buyer can use the quantified cost and cost driver information resulting from a TCO analysis to communicate to the supplier which activities cause higher costs on his side, increasing his bargaining power and in turn supply

0361-3682/\$ - see front matter (C) 2008 Published by Elsevier Ltd. doi:10.1016/j.aos.2008.05.005 
chain performance (e.g., Ellram, 1995; Roodhooft, Van den Abbeele, \& Peeters, 2005). However, due to buyers' reluctance to share the information needed for interfirm cost minimization, firms may fail to maximize possible gains from buyer-supplier negotiations (Baiman \& Rajan, 2002). Drake and Haka (2008) show, for instance, that concerns about inequity may lead to reluctance to share detailed accounting information. In this study, we investigate whether bargaining power may prevent buyers from sharing private TCO information and whether this might result in less effective negotiation outcomes between buyers and suppliers.

Power can be broadly defined as the capacity to exert influence on other people (Kelley \& Thibaut, 1978). Although power may derive from a variety of "power bases", it is the mutual dependence of individuals that allows power differences to exist. Accordingly, in interfirm relations, power is evidenced as the availability of alternatives (e.g., Anderson \& Dekker, 2005). Prior research indicates that power differences influence information search strategies and drive the processing of information about other people (e.g., De Dreu \& Van Kleef, 2004; Fiske, 1993). These studies suggest that power may be pivotal in the interplay between, on the one hand, the need to share information in order to optimize activities across the supply chain and, on the other hand, the reluctance to share private information.

This paper reports the results of a buyer-supplier negotiation experiment in which we manipulate both the cost information and the power of the buyer in order to assess whether access to detailed TCO information benefits buyers across different power settings. Based on social exchange theory (e.g., Emerson, 1976; Thibaut \& Kelley, 1959) and recent research on information processing in negotiations (e.g., De Dreu \& Carnevale, 2003), we expect that less powerful buyers who have detailed TCO information at their disposal may try to (re)gain control over negotiation outcomes by sharing information and creating integrative bargaining situations. Our results indicate that TCO information reduces the performance disadvantage of less powerful buyers, and further that this moderation effect is mediated by buyers' bargaining behavior; that is, less powerful buyers with TCO information use more problem solving techniques and fewer distributive bargaining techniques than more powerful buyers or buyers that lack TCO information. These results imply that less powerful buyers can compen- sate for their power disadvantage by acquiring more detailed TCO information. However, the results also suggest that powerful buyers seem unable to use TCO information to exploit their power advantage in order to obtain even greater individual profits. We therefore conclude that a position of power may impede the sharing of TCO information, resulting in suboptimal negotiation outcomes between buyers and suppliers.

This paper contributes to the existing literature on buyer-supplier relations and the use of accounting information in three significant ways. First, we analyze empirically whether buyers profit from TCO information when negotiating with suppliers. The literature on TCO discusses its adoption and its potential benefits (e.g., Carr \& Ittner, 1992; Ellram, 1995; Wouters et al., 2005). For example, these studies have argued that TCO can be used not only to compare and evaluate different suppliers, but also to provide decision-makers with an objective and easily understood argument to support purchasing decisions. It has also been suggested that a buyer can use the cost and cost driver information resulting from a TCO analysis to communicate to the supplier which activities cause higher costs on his side, increasing his bargaining position (e.g., Ellram, 1995; Roodhooft, Hiel, Van den Abbeele, \& van Doveren, 2003, 2005). However, there is little empirical research on the use of TCO during actual buyer-supplier negotiations. To our knowledge, this study is the first to investigate whether buyers can benefit from TCO when negotiating with suppliers.

Our second contribution is to add to a small but growing body of work on the role of accounting information in negotiations. The existing research on accounting negotiation has mainly focused on three intrafirm issues: collective bargaining (e.g., Craft, 1981; Waterhouse, Gibbins, \& Richardson, 1993), transfer pricing (e.g., Kachelmeier \& Towry, 2002; Luft \& Libby, 1997), and budgeting (e.g., Fisher, Frederickson, \& Peffer, 2000, 2006). The literature on interfirm accounting negotiations has primarily concentrated on auditor-client interactions (e.g., Bame-Aldred \& Kida, 2007; Gibbins, Salterio, \& Webb, 2001; Ng \& Tan, 2003; Windsor \& Ashkanasy, 1995). Although some of these studies consider the importance of power in negotiations (e.g., Gibbins et al., 2001; Ng \& Tan, 2003; Windsor \& Ashkanasy, 1995), they typically do not consider the role of sharing private cost information. Furthermore, auditor-client negotiations are often viewed as mainly distributive. An important reason 
is that audit clients seem to be inclined to negotiate within a single-issue framework, which acts as a barrier to finding integrative solutions (Gibbins, McCracken, \& Salterio, 2005). Conversely, we expect (and our results provide evidence) TCO to be a tool that may support buyers in adopting a multipleissue framework during buyer-supplier negotiations, which may enable buyers to create integrative bargaining situations. Overall, accounting research on interfirm negotiations beyond the specific auditing context has been very limited. This paper answers recent calls for empirical research "with a greater emphasis upon business processes and the use of accounting in action/negotiation" (Tomkins, 2001, p. 164).

Our third contribution lies in the application of a more sophisticated causal model to test for mediated moderation effects of negotiation behavior on negotiation outcomes. In an extensive review of theory-consistent management accounting research, Luft and Shields (2003) conclude that the majority of management accounting studies employ additive causal-model forms. Because such forms may limit our understanding of management accounting by representing causes and effects as universal rather than conditional on other mediating or moderating variables, Luft and Shields (2003) recommend the use of more sophisticated causal models. ${ }^{1}$ Muller, Judd, and Yzerbyt (2005) observe that mediation and moderation may be combined in informative ways to better understand causal effects. However, while well-developed and validated procedures exist for examining whether treatment effects on an outcome are mediated and/or moderated, very few studies analyze mediation and moderation simultaneously. This study uses a rigorous three-step approach to causal modeling in order to test for mediated moderation effects (cf. Baron \& Kenny, 1986). Our analyses indicate that TCO information reduces the performance disadvantage of less powerful buyers, and that this moderation effect is mediated by buyers' bargaining behavior. Studying this mediated moderation effect allows us to explain the

\footnotetext{
${ }^{1}$ More specifically, if the proposed causal model is additive, Luft and Shields (2003, p. 198) recommend providing both the reasons for assuming there are no important mediation or moderation effects and the consequences of omitting these relations if they exist. In other words, the default expectation is that there are important mediation and moderation effects that we should account for.
}

seemingly counterintuitive negotiation outcomes that we find.

The next section reviews the relevant literature and develops our hypotheses. Section three presents an outline of the experimental procedures and section four reports the results. Section five provides discussion and suggestions for future research.

\section{Theoretical background and hypotheses}

Our hypotheses are based upon social exchange theory $^{2}$ (e.g., Emerson, 1976; Thibaut \& Kelley, 1959). Social exchange theory describes negotiation as a process characterized by information exchange, joint problem solving, and persuasion. In this framework, negotiation outcomes (e.g., level of buyer and/or supplier satisfaction, profits, whether or not agreement is reached) result from the complex interaction of three constructs: negotiator characteristics, situational characteristics, and the characteristics of the negotiation process itself (Campbell, Graham, Jolibert, \& Meissner, 1998). Negotiator characteristics and situational characteristics are seen as affecting both process-related behaviors and performance outcomes. In this study, we control for negotiator characteristics and focus on two situational characteristics: the availability of TCO information and the relative power of the buyer. Based on social exchange theory, we predict that the effect of these situational characteristics on negotiation outcomes is mediated by the negotiation process.

The negotiation process may be thought of as a series of interactions (Kelley \& Thibaut, 1978).

\footnotetext{
${ }^{2}$ Although economic models have become the mainstream explanatory models in many business disciplines, it has been argued that advice to negotiators should depend on an understanding of the opponent's actual decision process, rather than on the assumption that the other party is fully rational (Bottom, Holloway, Miller, Mislin, \& Whitford, 2006). Indeed, recent research suggests that negotiation behavior is seldom rational (for a review, see Bazerman, Curhan, Moore, \& Valley, 2000). For example, evidence shows that despite the existence of an agreement zone, deviations from rationality in individual decisions lead to disagreements and Pareto-inefficient agreements. The problem with economic models is that researchers are subject to the empirical indeterminacy of economic phenomena (Emerson, 1976). In most real-life situations, many different outcomes (from full cooperation to near-disastrous conflict) are consistent with "rationality". Thus, game-theoretic models rarely provide unique predictions of negotiation outcomes. Behavioral decision models, such as exchange models, offer a set of adjustments to rational models (Murnigham \& Bazerman, 1990).
} 
According to social exchange theory, communication between parties during these interactions is very important, as it shapes their perceptions of each other and their interpretation of subsequent actions (e.g., Bottom et al., 2006). ${ }^{3}$ Communication influences the development of a relationship, because it provides an opportunity to express interest in the exchange partner, to ascertain the exchange partner's openness to reciprocity and to influence the exchange partner's perceptions. Generally, two basic types of negotiation behavior are distinguished within the negotiation process: problem solving and distributive bargaining (Walton \& McKersie, 1966). Problem solving primarily involves discovering ways to increase the benefits available in the relationship (Walton \& McKersie, 1966). In the context of purchasing, bargaining is integrative to the extent that buyers actively seek coordination with suppliers to develop alternative purchasing arrangements that are likely to reduce costs and/or increase performance. The intent is to identify a solution via open and accurate information exchange and to make trade-offs based on priorities and mutual respect for the other party's individual goals (Campbell et al., 1998). In contrast, distributive bargaining is a process whereby each party tries to maximize their private outcome (Walton \& McKersie, 1966). Distributive bargaining is characterized by the use of fixed-sum or "win-lose" tactics such as communicating threats, excessive demands, positional commitments, and persuasive arguments (Campbell et al., 1998). Prior studies indicate that distributive bargaining is "natural" or more salient to negotiators than problem solving (e.g., Weingart, Hyder, \& Prietula, 1996). Naive negotiators are more familiar with distributive tactics and therefore use these tactics as default approaches. This ties in with their assumption that the negotiation is a fixed-sum game (Bazerman et al., 2000).

\footnotetext{
${ }^{3}$ Verbal communication between buyers and suppliers, a very basic feature of interfirm negotiations, has not been systematically examined in accounting research. One reason may be that, according to economic models, such communications are irrelevant. The rationale is as follows: verbal claims made by either party are not verifiable and thus not strategically credible, so they will be ignored and should not influence the actions taken by rational self-interested counterparts (Bottom et al., 2006). This paper reports a detailed analysis of verbal communication of accounting information during buyer-supplier negotiations. The results provide clear evidence of the importance of this type of communication.
}

The main effects of cost information and power on negotiation behavior and outcomes

\section{Cost information}

A prerequisite for any buyer-supplier relationship is that cost information between exchange partners is shared (e.g., Dekker, 2003, 2004; Tomkins, 2001). Shared cost information can be used to analyze the value chain in order to identify cost-reduction opportunities across the companies' boundaries. Value chain analysis (VCA), introduced by Porter (1985) and further developed by Shank (1989) and Shank and Govindarajan (1992), allows one to analyze, coordinate, and optimize linkages between activities in the value chain by focusing on the interdependence between these activities (Dekker, 2003).

Traditionally, purchasing was simply a matter of negotiating the best price. Accordingly, under traditional management accounting, purchasing decisions tend to track only the purchase price associated with a particular supplier, burying all the other costs the supplier may introduce in the value chain of the purchasing organization (Carr \& Ittner, 1992; Degraeve \& Roodhooft, 1999). Traditional accounting systems are therefore unable to adequately support a VCA (Porter, 1985). In contrast, total cost of ownership (TCO) systems, which attempt to quantify all the costs associated with the purchase of a given product or service, presume the existence of boundary-spanning activities (Wouters et al., 2005) and hence start from a value chain perspective (Shank \& Govindarajan, 1992). The cost and cost driver information resulting from TCO analysis can be used to optimize the performance of activities across the supply chain (Porter, 1985). For instance, suppliers can be made aware of the extra costs they generate and also of ways to improve their competitive position by reducing these costs on the buyer's side (e.g., Ellram, 1995; Roodhooft et al., 2003, 2005). TCO information therefore helps buyer-supplier partners detect trade-offs along the value chain and improve profitability by modifying the way in which they do business with each other (Wouters et al., 2005). Accordingly, we expect that:

Hla: Buyers with TCO information achieve higher individual profits than buyers with traditional cost information.

In order to reach integrative agreements that lower the total costs over the value chain, buyers
266

267

268

269

270

271

272

273

274

275

276

277

278

279

280

281

282

283

284

285

286

287

288

289

290

291

292

293

294

295

296

297

298

299

300

301

302

303

304

305

306

307

308

309

310

311

312

313 
need to have a good understanding of their own priorities, communicate these to the supplier, and integrate information about suppliers' preferences into their own understanding of the problem at hand so that they can make trade-offs between important and unimportant issues (De Dreu, Beersma, Stroebe, \& Euwema, 2006). Prior research suggests that the availability of quantified information increases the likelihood that buyers engage in such problem solving efforts. For example, evidence has been provided that financial quantifications carry more weight in decisions than non-financial information (Ittner, Larcker, \& Meyer, 2003), that quantified information enhances persuasion, especially if it is regarded as objective (Kadous, Koonce, \& Towry, 2005), and that relatively abstract costs are less salient than outright losses (Northcraft \& Neale, 1986). Since TCO systems attempt to quantify all relevant costs (as opposed to traditional cost systems, which focus on price and do not quantify other costs), and since quantified costs carry more weight in decisions, TCO systems provide better insights into the relative importance of different costs. Hence, they provide relevant information that enlarges the set of possible outcomes in a negotiation, which in turn leads to better problem solving (e.g., Kersten, 2001). As buyers have greater insight into their own constraints and objectives, and as the quantified costs within TCO information are more persuasive than traditional accounting information, buyers are better-placed to cooperate with suppliers on identifying and assessing alternative courses of action. Thus, the availability of TCO information should encourage buyers to engage in problem solving efforts. Accordingly, we expect that:

H1b: Buyers with TCO information use more problem solving techniques than buyers with traditional cost information.

Power

Among the variables identified as factors influencing negotiation processes and outcomes, power is one of the most important (De Dreu \& Van Kleef, 2004). Existing research on negotiations in accounting settings shows that various sources of power may have an important impact on negotiation processes and outcomes (e.g., Fisher et al., 2000; Ng \& Tan, 2003). In particular, the power that results from the availability of alternative negotiation partners is a key element of many negotiations: indeed, if other negotiation partners are available, this reduces a party's dependence on the other side, which weakens the other party's power position (Giebels, De Dreu, \& Van de Vliert, 2000; Thibaut \& Kelley, 1959). Further, empirical research shows that negotiators with a viable alternative achieve higher personal outcomes than negotiators without alternative options or with less attractive ones: negotiators with less power tend to demand less, make more concessions, and achieve less successful outcomes than those with more power (Pinkley, Neale, \& Bennett, 1994). ${ }^{4}$ We therefore expect that:

H2a: More powerful buyers achieve higher individual profits than less powerful buyers.

Turning again to negotiation behavior, a buyer's relative power is expected to affect his bargaining aggressiveness. In particular, buyers' use of distributive bargaining techniques, which include implicit or explicit threats (e.g., warning the supplier that he is in danger of losing the contract), are likely to rise with supplier competition. First, such techniques are more credible when several suppliers are interested in a contract. Second, increased supplier competition reduces the buyer's need to solve problems with any given supplier or group of suppliers (Perdue \& Summer, 1991). Consequently, we expect that:

$H 2 b$ : More powerful buyers use fewer problem solving techniques and more distributive bargaining techniques than less powerful buyers.

The mediated moderation effect of cost information on the relation between power and individual profit

Prior research indicates that power not only influences strategic decisions such as the use of distributive bargaining techniques during negotiation, but also drives the processing of information (e.g., De Dreu \& Carnevale, 2003). For instance, compared to individuals with a power advantage, those at a power disadvantage are more motivated to understand the other's needs, desires, and possible actions (Gelfand \& Christakopoulou, 1999) and seek more situational control by making a positive impression (Goodwin, Gubin, Fiske, \& Yzerbyt, 2000). Further, negotiators with less power ask diagnostic rather

\footnotetext{
${ }^{4}$ For a more extensive review of the effects of power, see Van Kleef, De Dreu, Pietroni, and Manstead, 2006.
} 
than leading questions and belief-congruent rather than incongruent questions when facing a competitive partner rather than a cooperative one (De Dreu \& Van Kleef, 2004). These findings suggest that, compared to more powerful individuals, less powerful individuals have a higher epistemic motivation, i.e., a greater tendency to engage in information acquisition and processing, and thus a greater desire to develop and maintain a rich and accurate understanding of the opponent's intentions and behavior (Van Kleef et al., 2006). Because of their high epistemic motivation, dependent buyers may try to (re)gain control over their own outcomes by paying close attention to suppliers in order to accurately predict their intentions and behaviors (De Dreu \& Van Kleef, 2004). In contrast, powerful individuals are less likely to seek detailed information as they have more resources available and/or are less dependent on others, enabling them to act as they want without serious consequences (Fiske, 1993; Keltner, Gruenfeld, \& Anderson, 2003; Van Kleef et al., 2006). Because of their lower levels of epistemic motivation, powerful buyers are more likely to solve problems and to form an impression of their opponent through a quick, effortless, and heuristic processing of information that rests on well-learned prior associations (De Dreu \& Van Kleef, 2004). As distributive bargaining behavior is more salient to negotiators than problem solving behavior (e.g., Weingart et al., 1996), we expect powerful buyers to rely on distributive bargaining rather than on problem solving techniques.

With regard to the implication of power across TCO versus traditional information, it was already pointed out that buyers with traditional information, irrespective of whether they have power or not, are encouraged to focus on price; these buyers are less likely to take into account additional costs that the supplier may cause. This limited scope of information leaves traditional buyers (as opposed to TCO buyers) with fewer opportunities to propose a mutually acceptable solution, thus decreasing the likelihood of problem solving efforts.

Accordingly, we expect that less powerful buyers with TCO information may try to (re)gain control over their own outcomes by sharing information ${ }^{5}$

\footnotetext{
${ }^{5}$ We do not expect that less powerful buyers will hoard their private TCO information, as this would not be to their benefit. In order to benefit from TCO information, this needs to be exchanged so that trade-offs between important and unimportant issues can be made (Baiman \& Rajan, 2002; De Dreu et al., 2006).
}

and paying close attention to their opponent's intentions and behavior. That is, less powerful buyers with TCO information are more likely to use integrative bargaining techniques than either more powerful buyers with TCO information, who are more likely to using distributive bargaining techniques, or buyers without TCO information, who will be less able to create an integrative bargaining situation as their traditional cost information encourages them to focus solely on price. We therefore expect that:

H3a: Cost information moderates the effect of power on buyers' profits, such that TCO information reduces the performance disadvantage that less powerful buyers have compared to more powerful buyers.

$H 3 b$ : Cost information moderates the effect of power on buyers' bargaining behavior, such that TCO information encourages less powerful buyers to increase the use of problem solving techniques and to decrease the use of distributive bargaining techniques as compared to more powerful buyers.

$H 3 c$ : Buyers' use of problem solving and distributive bargaining techniques mediate the moderation effect of cost information on the relation between power and buyers' profits.

To summarize, we expect that the overall effect of power on the negotiation outcome will be moderated by cost information and that this moderation effect will be influenced by the effect of power and cost information on negotiation behavior (the mediator). These expectations are consistent with a mediated moderation hypothesis (Muller et al., 2005), as represented in Fig. 1.

\section{Research method}

Experimental design

To test our hypotheses, we developed a 2 (TCO information versus traditional cost information) $\times 2$ (equal power versus low power) experimental design, in which buyers and suppliers negotiate a lease contract for a set of machines. We manipulated the cost information and power of the buyer in order to assess whether access to detailed TCO information benefits buyers across different power settings. Cost information was 

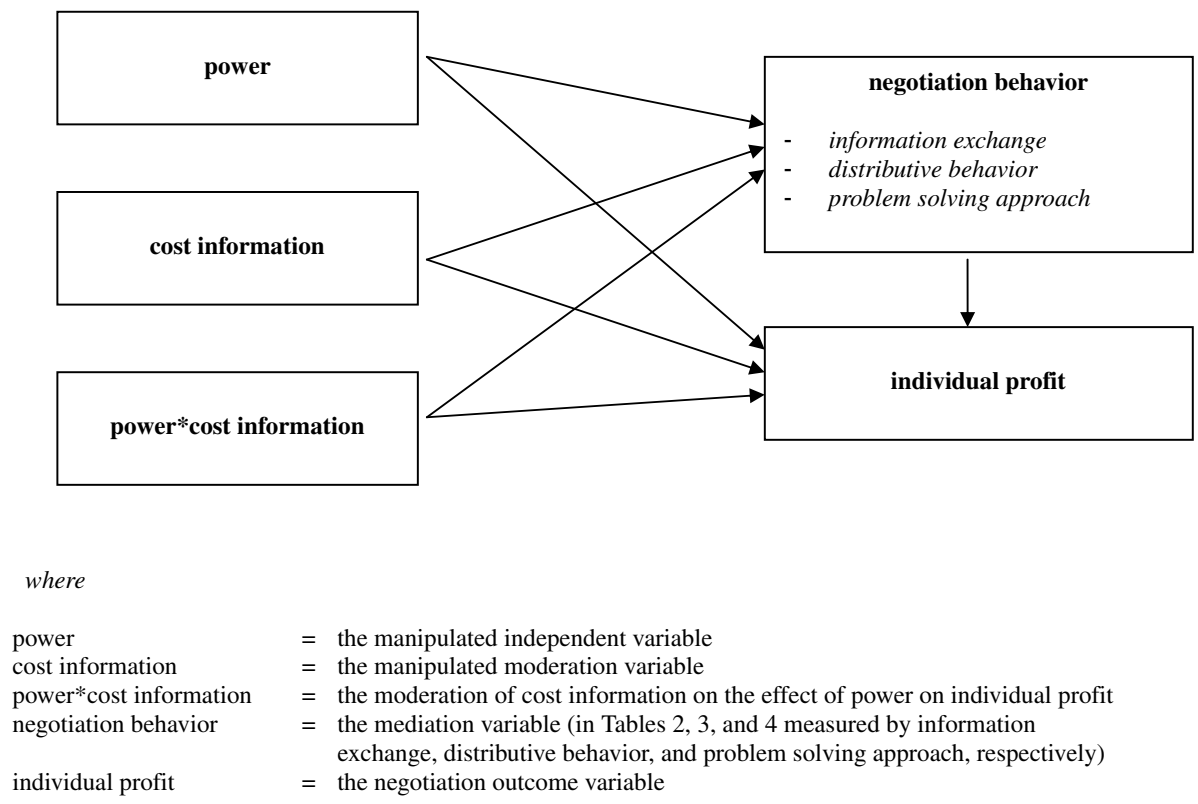

manipulated by providing the buyer with either TCO information or traditional cost information for the purchasing decision. The TCO information quantified all relevant costs (in this case: price, spare parts, and maintenance) associated with the purchase of a given quantity of products or services from a given supplier. All costs were expressed in the same currency as the price. Buyers with traditional information were given only an indication of the costs and of the relative importance of each of the issues to be negotiated (cf. Appendix A). This corresponds to traditional management accounting practices, which only track the purchase price and "bury" other purchasing costs in overhead accounts or general expenses (Carr \& Ittner, 1992). In addition, participants were informed that price is the most expensive cost, followed by maintenance and then spare parts. This information on the relative importance of the different issues provided buyers, who had traditional cost information at their disposal, with an understanding of their own preferences and priorities, which they could then communicate to the suppliers in order to reach an integrative solution.

We manipulated power through the availability of an outside option (e.g., Giebels et al., 2000; Pinkley et al., 1994). In the equal power setting, the written instructions for both the buyer and the supplier contained a short paragraph about the presence of an alternative negotiation partner. Buyers and suppliers were equally powerful, in the sense that they both had an outside option worth 1000 Euro. This outside option was relatively unattractive, however, as higher gains could be obtained by reaching an agreement. In the low power setting, buyers had no outside option and were fully dependent on reaching an agreement with their partner to earn any money. ${ }^{6}$ Suppliers always had an outside option of 1000 Euro and full cost and price information.

\begin{abstract}
${ }^{6}$ Consistent with prior research (for an overview, see Wolfe \& McGinn, 2005), the individual parties were aware of their own alternatives but not the other party's. If the buyer had no alternative, the buyer was told that in the short run the only supplier that could deliver the required machines was the supplier they were negotiating with. This made the buyer highly dependent on the supplier, but the supplier was unaware of this. This situation allows us to fully focus on the effects of the buyer's situation (information and power) and how this affects negotiation behavior and outcomes, without having to deal with the complexity of the supplier's perceptions of his or her power over the buyer. This manipulation also has the additional advantage of being a strong manipulation from the viewpoint of the buyer, without having to deal with the "obvious" result of virtually all of the profits going to the supplier if the latter was aware of the buyer's complete dependence.
\end{abstract}




\section{Subjects and procedures}

\section{The bargaining task}

Two hundred and eight participants were recruited from a graduate management accounting course that was part of a Master's program in business administration at a large West-European university. The course had covered traditional accounting methods, activity-based costing, TCO, and supplier selection problems before the experiment took place. The experiment was run in a computer laboratory. Each session was restricted to a maximum of one hour. The opportunity to earn a performance-based cash payout was the only incentive offered. Participants earned $0.5 \%$ of their company's profits (on average 5.74 Euro; $\min =0$ Euro; $\max =15$ Euro). The participants were randomly assigned to one of the four experimental conditions and to a buyer or a supplier role. Procedures were identical for all treatments.

Buyers and suppliers sat in different rooms so that they were unable to identify their partner's identity; personality effects and collusion were therefore precluded. Participants read the instructions describing their role and the nature of the bargaining task and could play the game at their own pace. The supplier started the game by making a first offer. Participants could send messages along with their offers and counteroffers if they desired to do so. All messages were recorded. The game ended when (i) an agreement was reached, (ii) a player opted for the outside option, or (iii) after 10 rounds. In the last case, participants were informed by the computer program that time was running out. This only happened in a few cases (4 out of 104).

The bargaining task is based on a negotiation game developed by Kelley (1966) and applied by many other researchers (e.g., Campbell et al., 1998; De Dreu \& Van Kleef, 2004). The game was adapted to suit a TCO setting. This means that the payoff tables in Kelley's game were replaced by cost tables for the buyers and cost and income tables for the suppliers. The tables were constructed in such a manner that the minimum and maximum profits that could be earned were the same for buyers and suppliers (cf. Appendix A). Buyers and suppliers had to negotiate a lease contract for a set of machines. The buyer could earn a fixed income (of 6000 Euro) by selling end products to an end customer. The instructions explained that maintenance and spare parts were needed to run the machines and to produce the end product. Consequently, the game involved the simultaneous negotiation of price, maintenance, and spare parts. For each of these issues, nine different contract terms were possible.

Price was an income for the supplier and a cost for the buyer. Accordingly, the price issue was distributive in nature. This issue was worth the same for each negotiator, with preferences on the issue going in opposite directions. Consequently, one party's gain was equal to the other party's loss. The task, however, provided an opportunity for the parties to integrate their personal interests. The buyer had a comparative advantage in taking care of the spare parts and the supplier had a comparative advantage in maintaining the machines. Since the issue that was most valuable to one party was automatically less valuable to the other party, it was possible for participants to trade-off issues. Such "logrolling", giving up on less valuable issues to maximize outcomes on the most valuable ones, could yield a fully integrative solution or a Paretooptimal solution (Kersten, 2001). The Pareto-optimal solution is the solution whereby neither dyad member can improve his situation without the other party being worse off; in other words, no other combination of contracts offers as much or more profit to both parties. The Pareto-optimal joint outcome could be reached when the buyer and supplier agreed on contract 5AZ. In this agreement, the distributive issue (price) is set at the middle and the two integrative issues (maintenance and spare parts) are fully traded off. In this situation, denoted with an asterisk $\left(^{*}\right)$ in Appendix A, the maximum level of joint profit was reached and was equally divided between the buyer and the supplier. ${ }^{7}$ As cost tables were private, participants had to find out the possibility of a win-win solution through the process of offers and counteroffers and by exchanging information about their interests.

Before the negotiations started, participants were informed that they should realize that their opponent's cost structure did not mirror their own cost structure. Participants were reminded that, just like

\footnotetext{
${ }^{7}$ The price contract did not influence the joint profits: maximum joint profits were reached as long as participants agreed on contract AZ. Nine (1AZ to 9IZ) different contract combinations led to maximum joint profits. However, only contract $5 \mathrm{AZ}$ divided the maximum joint profit equally between the buyer and the supplier.
} 
in real life, companies may have different competitive advantages and that, as a result, their company might be competitively better at maintenance than their opponent, while their opponent might be more competitive in spare parts (or vice versa). ${ }^{8}$ Furthermore, the instructions informed participants that at all times during the negotiation a table would be shown on their screen with an overview of their opponent's proposals and their own counter-proposals, so that they would have an overview of all proposals already made. ${ }^{9}$

\section{Dependent variables}

\section{Negotiation outcomes}

As we want to assess whether buyers can benefit from more refined TCO data in making purchasing decisions, this study focuses on the buyer's individual profit. This is the amount of money earned by a buyer at the conclusion of the negotiations; it is measured as the buyer's individual profit level asso-

\footnotetext{
${ }^{8}$ This was illustrated in the instructions by an example relating to maintenance. Buyers with TCO information were referred to the cost table for cells 1 and 2 in Appendix A: if they agreed on maintenance contract "A", their company would have a relatively low maintenance cost ( $€ 250$ ), but the supplier would have to provide the maximum level of maintenance. It was explained that this did not mean that the supplier's cost for providing this level of maintenance would be $€ 2250$, as this was the cost to the buyer if he were to provide the maximum level of maintenance himself; rather, this amount was different from what the supplier would have to pay in order to provide the same maintenance level, since the cost structures of both companies were different. The instructions also explained that the same reasoning was to be applied to spare parts. Buyers with traditional cost information were referred to the cost table for cells 3 and 4 in Appendix A and were provided with the same text, except that the cost figures were replaced by the corresponding number of maintenance sessions (as provided in the cost table for cells 3 and 4 in Appendix A).

${ }^{9}$ The information in this table was essentially the same in all experimental cells. The table provided an overview of all proposals made by both players (e.g., proposal supplier: 6EV; counter-proposal buyer: 4DW; counter-proposal supplier: 5CA; etc.). Thus, at all times during the negotiation, participants could check the history of proposals and counter-proposals made. Participants with TCO information also received the corresponding profit or loss figure for the different offers. This figure provided no new or extra information, as participants with TCO information could easily compute this figure from the information provided in their private cost tables. This information was solely provided for the purpose of speeding up the game. The profit/loss figure was not provided in experimental cells with traditional information: participants in these experimental cells could derive the corresponding number of maintenance sessions and spare parts from their private cost tables, but not the exact corresponding costs.
}

ciated with final agreement in the negotiation. Although this is not central to the analysis, the study also briefly discusses the results relating to the supplier's individual profit and the dyad's joint profit, as these provide a deeper understanding of the study's main findings.

\section{Negotiation behavior}

Negotiation behavior is derived from two sets of measures: (1) a set based on interaction analysis, and (2) a set based on participants' responses to the post-game questionnaire administered immediately following the negotiation exercise.

First, verbal behavior is coded by means of interaction analysis in order to examine categories and meanings embedded in structural patterns of communication (Putman \& Fairhurst, 2001). The classification scheme, which is included in Appendix B1, is based on negotiation communication coding schemes used in prior studies (e.g., Giebels et al., 2000). Three judges, who were blind to conditions or hypotheses, coded each negotiation independently. Inter-rater agreements, expressed in Cohen's Kappa, varied between 0.75 and 0.95 . After completing the coding, the coders compared their coding and resolved disagreements by jointly revisiting the negotiation messages and producing a single set of codes for each subject. Negotiation behavior is determined by analyzing this last set of codes. Messages sent by participants were coded for (i) problem solving techniques, measured as information exchange and as other integrative behaviors, and (ii) distributive bargaining techniques, such as sending threats or issuing warnings. Information exchange reflects the extent to which a participant shared information about priorities. Information exchange was coded " 0 " for participants not revealing any information about their cost structure, " 1 " for participants revealing the relative importance (but not the numerical values) of each of the three issues under negotiation, and " 2 " for participants revealing both the relative importance and the numerical values of each of the three issues under negotiation. Integrative behavior is based on the average of two measures: the number of rewards offered and the number of positive normative appeals extended (Cronbach's alpha $=0.70$ ). Integrative behavior is also assessed by counting the number of explicit requests for cooperation. However, as the number of requests for cooperation did not load with the rewards and the positive normative appeals on one factor, it is treated as a sep- 
arate measure. Distributive behavior is a summated scale calculated by adding five types of distributive bargaining techniques together and determining the mean value. The five behavior types included are as follows: general threats, exit threats, warnings, commitment and punishments (Cronbach's alpha $=0.81$ ).

Second, negotiation behavior is derived from post-game questionnaires. Participants rated their opponent's bargaining behavior on four items that measure the overall problem solving approach of the buyers as assessed by the supplier (Cronbach's alpha $=0.88$. The different items are listed in Appendix B2 and are based on prior studies (e.g., Campbell et al., 1998). A summated scale was obtained by calculating the mean value across the four items.

\section{Results}

\section{Experimental checks}

After completing the negotiation task, participants filled out a post-bargaining questionnaire on a 1-5 scale, enabling us to check for motivation, task understanding, and their usage of cost reports. All checks on the experimental conditions (on cost information relevance and power) are statistically significant and have means in the appropriate direction. More powerful buyers considered themselves more powerful $(F(1,102)=14.61, p<0.01)$ and buyers with TCO information judged the cost information they received to be more relevant than buyers with traditional cost information $(F(1$, $102)=41.62, \quad p<0.01)$. Checks on procedures, including the subject's involvement in the task, their understanding of instructions and payoff tables, and whether they had sufficient time to complete the exercise, show no differences between conditions $(p>0.10)$, as is appropriate. Means on these questions indicate that subjects were highly involved (mean $=4.33$; std $=0.69)$, that they assessed the exercise as "fun" (mean $=4.07$; std $=0.70)$, that they understood both the instructions (mean $=4.41$; std $=0.77$ ) and the payoff tables (mean $=4.62$; std $=0.51)$, and that they had enough time to complete the task (mean $=4.40$; std $=0.98)$. Participants in different experimental cells required an equal amount of time to read the instructions and familiarize themselves with the game before actually starting the negotiation $(p>0.10)$. On average, participants needed $559 \mathrm{~s}(9.3 \mathrm{~min})$ to read the instruc- tions. Participant gender produced neither main nor interaction effects on negotiation process or outcomes and is therefore excluded from further analysis.

The effects of cost information and power on negotiation outcomes

Table 1 presents the results. ${ }^{10}$ A correlation matrix of all variables included in the study is provided in Appendix C. As expected in H1a, buyers with TCO information obtained significantly higher individual profits than buyers with traditional cost information $(F(1,100)=52.90, p<0.01)$. Consistent with $\mathrm{H} 2 \mathrm{a}$, more powerful buyers generated higher individual profits than less powerful buyers $(F(1,100)=14.02, p<0.01)$. The results also indicate a moderation effect of cost information on the overall effect of power on individual profit $(F(1,100)=4.58, p<0.05)$. The performance deficit of less powerful buyers actually disappeared when they had TCO information: the individual profit made by buyers with TCO information and an outside option did not significantly differ from the profit made by buyers who had access to the same information but no outside option (buyer's mean individual profit $=1148.33$ versus buyer's mean individual profit $=1007.69 ; \quad F(1,54)=2.46$, $p>0.10$ ). The performance deficit of less powerful buyers was thus less pronounced when buyers had detailed TCO information, supporting $\mathrm{H} 3 \mathrm{a}$.

\section{The effects of cost information and power on negotiation behavior}

To explain negotiation outcomes, we analyze participants' negotiation behavior. First, we test $\mathrm{H} 1 \mathrm{~b}$, which predicts that buyers with TCO information use problem solving techniques more frequently than buyers with traditional cost information. An ANOVA on information exchange reveals a main effect for cost information $(F(1,100)=6.14$,

(1)

\footnotetext{
${ }^{10}$ Analyses are performed for all subjects in the study. However, we obtain similar results when excluding the subjects that opted for an outside option and thus did not reach agreement. Only 14 out of 208 subjects opted for this outside option, which may be explained by the fact that the outside option was relatively unattractive, as higher gains could be obtained by reaching an agreement. Pairwise comparisons with Tukey tests indicate that the number of dyads choosing for an outside option is not significantly different across the four experimental conditions $(p>0.10)$
} 
Table 1

Analysis of negotiation outcomes and buyer's behavior

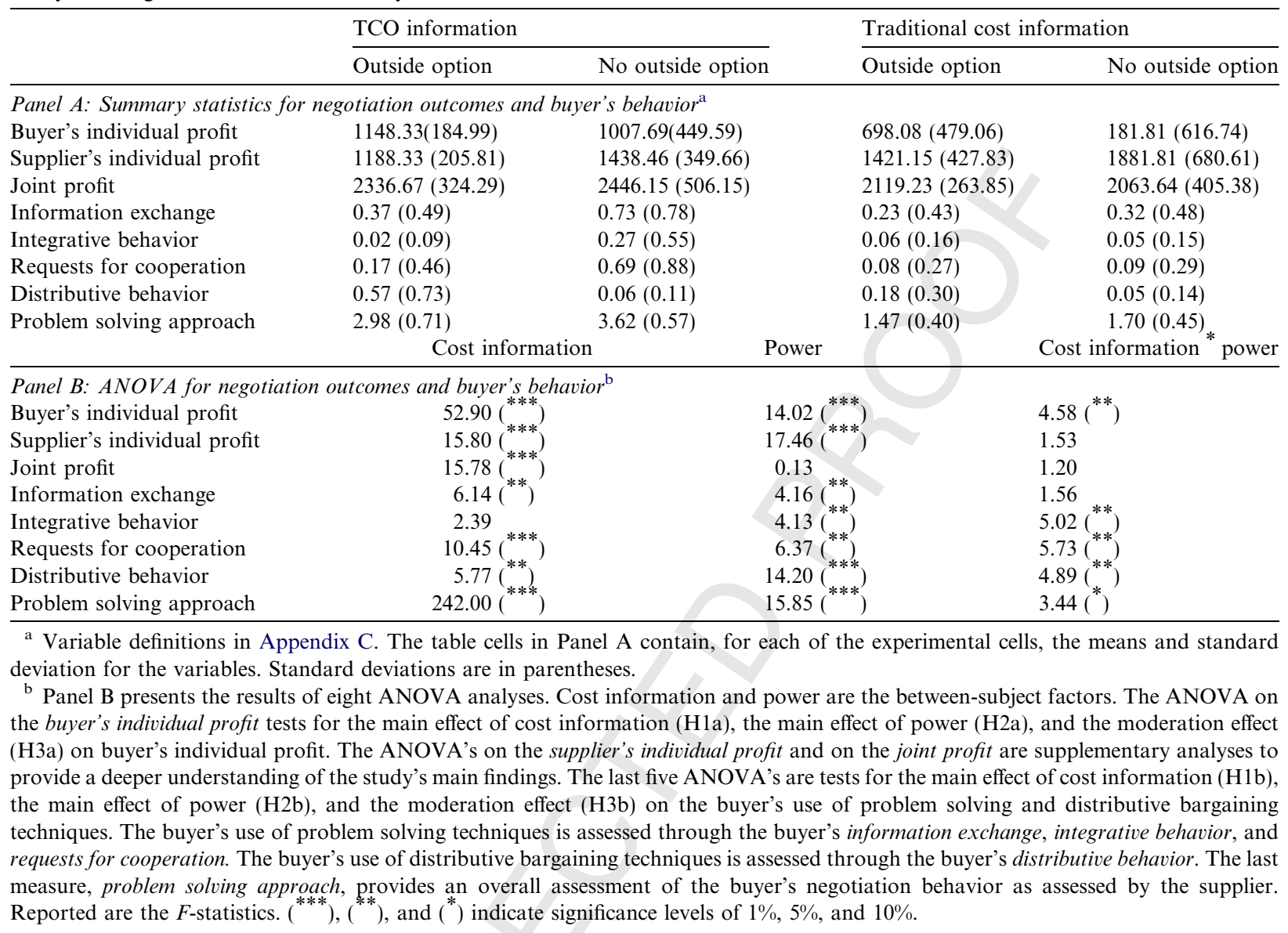

$p<0.05$ ): buyers with TCO information disclosed more information than buyers with traditional information. An ANOVA on integrative behavior indicates that the effect for cost information $(F(1$, $100)=2.39, p=0.12)$ is not significant at the $10 \%$ level, but closely approaches significance. An ANOVA on the number of explicit requests for cooperation shows a main effect for cost information $(F(1,100)=10.45, p<0.01)$, indicating that buyers with TCO information requested active cooperation more frequently than buyers with traditional cost information. Buyers' negotiation behavior is further examined by an ANOVA on the composite measure problem solving approach. A significant main effect for cost information is found $(F(1,100)=242.00$, $p<0.01$ ), indicating that, according to the suppliers, buyers with TCO information used problem solving techniques more frequently than buyers with traditional information. Although the effect of cost information on integrative behavior is somewhat weaker, the effects of cost information on information exchange, requests for cooperation and problem solving approach, provide strong support for $\mathrm{H} 1 \mathrm{~b}$. The ANOVA on distributive behavior reveals an unexpected main effect of cost information $(F(1$, $100)=5.77, p<0.05$ ), indicating that TCO information significantly increased the use of distributive bargaining techniques. Unreported Tukey tests indicate that this effect is mainly driven by buyers with TCO information and an outside option, as these buyers used distributive bargaining techniques more frequently than buyers in the other three conditions $(p<0.01)$. The Tukey tests also indicate that buyers with TCO information but no outside option did not use distributive bargaining techniques more frequently than buyers in the two conditions with traditional information $(p>0.10)$.

In order to test $\mathrm{H} 2 \mathrm{~b}$, we analyze the effect of power on the negotiation behavior variables. An ANOVA on information exchange shows a main
815

816

817

818

819

820

821

822

823

824

825

826

827

828

829

830

831

832

833

834

Please cite this article in press as: Van den Abbeele, A. et al., The effect of cost information on buyer-supplier negotiations ..., Accounting, Organizations and Society (2008), doi:10.1016/j.aos.2008.05.005 
effect for power $(F(1,100)=4.16, p<0.05)$ : more powerful buyers disclosed less information than less powerful buyers. The main effects of power on integrative behavior $(F(1,100)=4.13, p<0.05)$ and on the number of explicit requests for cooperation $(F(1,100)=6.37, p<0.05)$ indicate that more powerful buyers used fewer integrative bargaining techniques and formulated fewer requests for cooperation than buyers without an outside option. We also find a strong main effect of power on distributive behavior $(F(1,100)=14.20, p<0.01)$, indicating that power significantly increased the use of distributive bargaining techniques. Finally, buyers' overall negotiation behavior is examined by means of the composite measure problem solving approach. A significant main effect is found for power $(F(1$, $100)=15.85, p<0.01)$. Thus, according to the suppliers, less powerful buyers adopted problem solving strategies more frequently than buyers with an outside option. Overall, these results provide strong support for $\mathrm{H} 2 \mathrm{~b}$.

Finally, with respect to $\mathrm{H} 3 \mathrm{~b}$, we examine whether cost information moderates the overall effect of power on negotiation behavior. Although the ANOVA on information exchange indicates that the moderation effect of cost information on power is not significant at the $10 \%$-level, pairwise comparisons with Tukey tests indicate that buyers with TCO information and no outside option exchanged information more frequently than buyers with TCO information and an outside option $(p<0.10)$. We find that cost information has a significant moderation effect on the relationship between power and integrative behavior $(F(1,100)=5.02, p<0.05)$. Pairwise comparisons with Tukey tests indicate that buyers with TCO information and no outside option used integrative bargaining techniques more frequently than buyers in the three other conditions $(p<0.10)$. Cost information also moderates the effect of power on the number of explicit requests for cooperation $(F(1,100)=5.73, p<0.05)$. Pairwise comparisons with Tukey tests indicate that buyers with TCO information and no outside option requested active cooperation more frequently than buyers in the three other conditions $(p<0.01)$. Additionally, we find a moderation effect of cost information on the overall effect of power on distributive behavior $(F(1,100)=4.89, p<0.05)$. Pairwise comparisons with Tukey tests reveal that buyers with TCO information and an outside option used significantly more distributive bargaining techniques than buyers in the other three experimental conditions $(p<0.01)$. Finally, we also find a significant moderation effect on problem solving approach $(F(1,100)=3.44, p<0.10)$. Pairwise comparisons with Tukey tests indicate that, according to the suppliers, buyers with TCO information and no outside option made more extensive use of problem solving techniques than buyers in the other conditions $(p<0.01)$. Overall, these results on the moderating effect of cost information on the relation between power and negotiation behavior, provide support for $\mathrm{H} 3 \mathrm{~b}$.

The mediated moderation effect of cost information on the relation between power and individual profit

Based on exchange theory, we hypothesize in $\mathrm{H} 3 \mathrm{c}$ that the negotiation process has a mediation effect on the negotiation outcome. More specifically, we expect the nature of negotiation behavior to mediate the moderation effect of cost information on the overall effect that power has on individual profit (cf. Fig. 1). Since the effect of power on negotiation outcomes is moderated by cost information and since we expect this moderation effect to be mediated by negotiation behavior, we use Baron and Kenny's (1986) framework for combining moderation and mediation. We perform the analyses for the two main types of bargaining behavior: problem solving behavior (operationalized as information exchange) and distributive behavior. ${ }^{11}$ In a sensitivity analysis, we also conduct the analysis for the measure of the overall problem solving approach of the buyers as assessed by the supplier.

\footnotetext{
${ }^{11}$ Baron and Kenny (1986) procedure to test for mediation and moderation is designed to test the effects of a single moderator and a single mediator. In the present analysis, however, we are interested in the mediating effects of problem solving as well as distributive bargaining. Accordingly, we perform the procedures for the different mediating variables separately. Table 2 introduces (in Step 3) information exchange and its interaction term with cost information, whereas Table 3 introduces (again in Step 3 ) distributive behavior and its interaction effect with power. The mediation-moderation procedure is not performed for the combination of distributive behavior and cost information, because we only expect an effect of TCO on problem solving behavior and not on distributive behavior (cf. H1b). Because we expect power to affect problem solving (cf. H2b), we also performed the mediation-moderation procedure for the combination of information exchange and power. The results are not significant and are therefore not reported. To test for overall mediating effects, we conduct the analyses reported in Table 5. Although this overall test provides an interesting addition to the three-step procedures listed in Tables $2-4$, it is not sufficient in itself to demonstrate mediated moderation (Muller et al., 2005).
} 
Table 2

Three-step regression procedure for testing mediation and moderation of information exchange ${ }^{\mathrm{a}}$

\begin{tabular}{|c|c|c|c|c|}
\hline & \multirow{2}{*}{$\begin{array}{l}\text { Step 1 } \\
\text { Buyer's individual } \\
\text { profit }\end{array}$} & \multicolumn{2}{|l|}{ Step 2} & \multirow{2}{*}{$\begin{array}{l}\text { Step } 3 \\
\begin{array}{l}\text { Buyer's individual } \\
\text { profit }\end{array}\end{array}$} \\
\hline & & $\begin{array}{l}\text { Information } \\
\text { exchange }\end{array}$ & profit & \\
\hline $\begin{array}{l}\text { Constant } \\
\text { Cost information } \\
\text { Power } \\
\text { Power }{ }^{*} \text { cost information } \\
\text { Information exchange } \\
\text { Cost information }{ }^{*} \text { information } \\
\quad \text { exchange }\end{array}$ & $\begin{array}{r}181.82\left({ }^{*}\right) \\
825.87\left({ }^{* * *}\right) \\
516.26\left(\text { (**) }^{* * *}\right) \\
-375.62\left(^{* *}\right)\end{array}$ & $\begin{aligned} & 0.32\left(\begin{array}{l}* * * \\
\end{array}\right. \\
& 0.41\left({ }^{* *}\right) \\
- & 0.09 \\
- & 0.28\end{aligned}$ & $\begin{array}{r}165.53\left({ }^{*}\right) \\
804.75(* * *) \\
520.73(* * *) \\
-361.45\left(^{* *}\right) \\
51.19\end{array}$ & $\begin{array}{r}310.99\left(^{* * *}\right) \\
517.27\left(_{* * *}^{* *}\right) \\
480.77\left(^{* * *}\right) \\
\left.-250.73{ }^{* * *}\right) \\
-405.96\left(^{* * *}\right) \\
651.51\left(^{*}\right)\end{array}$ \\
\hline$R^{2} F$ for $R^{2}$ & $0.41\left(^{* * *}\right)$ & $0.11\left(^{* * *}\right)$ & $0.41\left(^{* * *}\right)$ & $0.49\left(^{* * *}\right)$ \\
\hline \multicolumn{5}{|c|}{$\begin{array}{l}\left({ }^{* * *}\right),\left({ }^{* *}\right) \text {, and }\left({ }^{*}\right) \text { indicate significance levels of } 1 \%, 5 \% \text {, and } 10 \% \text {. } \\
\text { a Variable definitions in Appendix C. This table presents our results on Baron and Kenny's (1986) three-step procedure to test whether } \\
\text { buyers' use of problem solving techniques (operationalized as information exchange) mediates the moderation effect of cost information on } \\
\text { the relation between power and buyers' profits (H3c). (See Table } 3 \text { for our test for distributive bargaining techniques.) The table above } \\
\text { presents the results of four regression analyses. In Step 1, the dependent variable buyer's individual profit is regressed on cost information, } \\
\text { on power, and on the moderation term power }{ }^{*} \text { cost information. In Step 2, the dependent variable information exchange is first regressed } \\
\text { on cost information, on power, and on the moderation term power }{ }^{*} \text { cost information. Then, the dependent variable buyer's individual } \\
\text { profit is regressed on cost information, on power, on the moderation term power }{ }^{*} \text { cost information, and on information exchange. In Step } \\
3 \text {, the dependent variable buyer's individual profit is regressed on cost information, on power, on the moderation term power }{ }^{*} \text { cost } \\
\text { information, on information exchange, and on the moderation term cost information }{ }^{*} \text { information exchange. Regression coefficients are } \\
\text { reported. }\end{array}$} \\
\hline
\end{tabular}

First, we consider the effect of information exchange. As shown in Table 2, this analysis proceeds in three steps. The first step is a regression analysis of power, cost information, and the moderation effect of cost information on the effect of power on individual profit. In the second step, two equations are estimated: (1) information exchange is regressed on power, on cost information, and on the moderation effect of cost information on the effect of power, and (2) individual profit is regressed on power, on cost information, on the moderation effect of cost information on the effect of power, and on information exchange. Eventually, in the third step, one equation is estimated: individual profit is regressed on power, on cost information, on the moderation effect of cost information on the effect of power, on information exchange, and on the moderation effect of cost information on information exchange. This last equation is identical to the second Step 2 equation, except that the moderation term of cost information on information exchange is now added. The key question is the extent to which the moderation effect of cost information on the relation between power and individual profit is reduced in moving from Step 2 to Step 3. Information exchange mediates the moderation effect of cost information on power if the following conditions are met (Baron \&
Kenny, 1986, p. 1179): (1) the moderation effect of cost information on power should affect individual profit less at Step 3 than at Step 2; (2) in Step 3, the moderation effect of cost information on information exchange should affect individual profit significantly; (3) finally, in Step 2 cost information should affect information exchange, which results in a correlation between the moderation effect of cost information on the effect of power (i.e., power ${ }^{*}$ cost information) and the moderation effect of cost information on the effect of information exchange (i.e., cost information * information exchange). As can been seen in Table 2, all these conditions are met. In Step 2, cost information significantly explains information exchange (coefficient $=0.41, \quad p<0.05), \quad$ and in Step 3 the moderation effect of cost information on information exchange significantly affects individual profit (coefficient $=651.51, p<0.01$ ). Furthermore, the moderation effect of cost information on the effect of power on individual profit is reduced in moving from Step 2 to Step 3, where it has dropped to a non-significant level (coefficient in Step $1=$ $-375.62, p<0.05$ and coefficient in Step $3=$ $-250.73, p>0.10)$, indicating "full" mediated moderation. These results imply that information exchange mediates the moderation effect of cost information on power. 
Table 3

Three-step regression procedure for testing mediation and moderation of distributive behavior ${ }^{\mathrm{a}}$

\begin{tabular}{|c|c|c|c|c|}
\hline & Step 1 & \multicolumn{2}{|l|}{ Step 2} & \multirow{2}{*}{$\frac{\text { Step } 3}{\text { Buyer's individual profit }}$} \\
\hline & Buyer's individual profit & Distributive behavior & Buyer's individual profit & \\
\hline Constant & $181.82\left(^{*}\right)$ & 0.05 & $179.73\left(^{*}\right)$ & 138.99 \\
\hline Cost information & $825.87\left(\begin{array}{c}* * * \\
* * *\end{array}\right)$ & 0.02 & $825.13\left(\begin{array}{c}* * * \\
* * *\end{array}\right)$ & $810.72\left(\begin{array}{c}* * * \\
* * *\end{array}\right)$ \\
\hline Power & $516.26\left(\begin{array}{c}* * * \\
* * *\end{array}\right)$ & 0.13 & $510.21\left(\begin{array}{c}* * * \\
* * *\end{array}\right)$ & $557.21\left(\begin{array}{c}* * * \\
* * *\end{array}\right)$ \\
\hline Power ${ }^{*}$ cost information & $-375.62\left(^{* *}\right)$ & $0.37\left(^{* *}\right)$ & $-392.81\left(^{* *}\right)$ & $-364.60\left({ }_{*}^{* *}\right)$ \\
\hline Distributive behavior & & & 46.00 & $942.23\left(\begin{array}{c}* \\
*\end{array}\right)$ \\
\hline Power ${ }^{*}$ distributive behavior & & & & $-931.62\left(^{*}\right)$ \\
\hline$R^{2} F$ for $R^{2}$ & $0.41\left(^{* * *}\right)$ & $0.21\left(^{* * *}\right)$ & $0.41\left(^{* * *}\right)$ & $0.42\left(^{* * *}\right)$ \\
\hline
\end{tabular}

$\left({ }^{* * *}\right),\left(^{* *}\right)$, and $\left(^{*}\right)$ indicate significance levels of $1 \%, 5 \%$, and $10 \%$.

a Variable definitions in Appendix C. This table presents our results on Baron and Kenny's (1986) three-step procedure to test whether buyers' use of distributive bargaining techniques mediates the moderation effect of cost information on the relation between power and buyers' profits (H3c). (See Table 2 for our tests for problem solving techniques.) The table above presents the results of four regression analyses. In Step 1, the dependent variable buyer's individual profit is regressed on cost information, on power, and on the moderation term power ${ }^{*}$ cost information. In Step 2, the dependent variable distributive behavior is first regressed on cost information, on power, and on the moderation term power * cost information. Then, the dependent variable buyer's individual profit is regressed on cost information, on power, on the moderation term power ${ }^{*}$ cost information, and on distributive behavior. In Step 3, the dependent variable buyer's individual profit is regressed on cost information, on power, on the moderation term power ${ }^{*}$ cost information, on distributive behavior, and on the moderation term power ${ }^{*}$ distributive behavior. Regression coefficients are reported.

The same three-step procedure is undertaken for distributive bargaining behavior (cf. Table 3). As shown by the results, neither cost information nor power has a significant effect on distributive behavior in Step 2. However, mediated moderation is also demonstrated (1) if the moderation effect of cost information on power has less of an effect on individual profit in Step 3 than in Step 2, (2) if the effect of power on distributive behavior is moderated by cost information in Step 2, and (3) if the effect of distributive behavior on individual profit is nonzero (Muller et al., 2005). As can been seen in Table 3 , all these conditions are met. In Step 2 the moderation effect significantly explains distributive behavior (coefficient $=0.37, p<0.05$ ), and in Step 3 distributive behavior significantly affects individual profit (coefficient $=942.23, p<0.10$ ). Furthermore, the moderation effect of cost information on the relation between power and individual profit is reduced in moving from Step 2 to Step 3 (though it does not drop to non-significance, providing evidence for "partial" mediated moderation). Finally, in a sensitivity analysis, the three-step procedure is also applied to determine the buyer's overall problem solving approach as assessed by the supplier (cf. Table 4). The results are very similar to those in Table 2. Overall, we conclude that the results reported in Tables 2 and 4 provide support for our expectation that the moderation effect of cost information on the relation between power and buyers' profits is mediated by buyers' problem solving behavior. Table 3 provides support that the moderation effect is partially mediated by the buyers' distributive bargaining behavior. Together, these results support $\mathrm{H} 3 \mathrm{c}$.

In a last set of analyses, we test for the overall mediation effect of the negotiation process (cf. Table 5). ${ }^{12,13} \mathrm{We}$ conduct a hierarchical regression analysis, in which dummy variables representing the manipulations are entered in Step 1 and the proposed sets of mediators are entered in Step 2 (cf.

\footnotetext{
12 The process variables in Table 5 are information exchange and distributive behavior (and their interaction with cost information and power, respectively). Replacing the information exchange variable by the problem solving behavior variable yields similar results.

${ }^{13}$ Finally, we perform several sensitivity analyses to test the robustness of the results against different ways of measuring negotiation behavior. First, similar results are obtained when information exchange is coded " 0 " for participants not revealing any information about their cost structure, and " 1 " for participants revealing the relative importance of each of the three issues (with or without the numerical values). Second, we analyze participants' ratings of their own bargaining strategies. The selfassessed problem solving behavior of the buyers correlates well with suppliers' assessment of buyers' problem solving behavior (Pearson correlation $=0.41, p<0.01$ ). However, as one of the four items (i.e., the question whether the participant was honest or deceptive) assessed by the buyers does not load with the other items on one factor, the problem solving construct is based on the supplier's assessment of the buyer's behavior. Similar results are obtained and hence the conclusions remain the same when the problem solving approach construct combines the items from both the suppliers' and the buyers' questionnaires.
}

1005

1006

1007

1008

1009

1010

1011

1012

1013

1014 
Table 4

Three-step regression procedure for testing mediation and moderation of problem solving approach ${ }^{\mathrm{a}}$

\begin{tabular}{|c|c|c|c|c|}
\hline & Step 1 & \multicolumn{2}{|l|}{ Step 2} & \multirow{2}{*}{$\begin{array}{l}\text { Step } 3 \\
\text { Buyer's } \\
\text { individual profit }\end{array}$} \\
\hline & $\begin{array}{l}\text { Buyer's } \\
\text { individual profit }\end{array}$ & $\begin{array}{l}\text { Problem } \\
\text { solving approach }\end{array}$ & $\begin{array}{l}\text { Buyer's } \\
\text { individual profit }\end{array}$ & \\
\hline Constant & $181.82\left(^{*}\right)$ & $1.71\left(\begin{array}{c}* * * \\
* * *\end{array}\right)$ & 174.60 & $1012.78\left(^{* * *}\right)$ \\
\hline Cost information & $825.87\left(\begin{array}{c}* * * \\
*\end{array}\right)$ & $1.91\left(^{* * *}\right)$ & $817.78\left(^{* * *}\right)$ & -666.23 \\
\hline Power & $516.26\left(\begin{array}{c}* * * \\
* * *\end{array}\right)$ & -1.45 & $517.25(* * *)$ & $402.48\left(^{* * *}\right)$ \\
\hline Power ${ }^{*}$ cost information & $-375.62\left(^{* *}\right)$ & $-1.85\left(^{*}\right)$ & $-373.89\left(^{* *}\right)$ & -144.73 \\
\hline Problem solving approach & & & 4.24 & $-487.50\left(\begin{array}{c}* * * \\
* * *\end{array}\right)$ \\
\hline Cost information ${ }^{*}$ problem solving approach & & & & $670.37\left(^{* * *}\right)$ \\
\hline$R^{2} F$ for $R^{2}$ & $0.41\left(^{* * *}\right)$ & $0.72\left(^{* * *}\right)$ & $\left.0.41{ }^{* * *}\right)$ & $0.49\left(^{* * *}\right)$ \\
\hline
\end{tabular}

$\left({ }^{* * *}\right),\left({ }^{* *}\right)$, and $\left(^{*}\right)$ indicate significance levels of $1 \%, 5 \%$, and $10 \%$.

a Variable definitions in Appendix C. This table reports a sensitivity analysis using Baron and Kenny's (1986) three-step procedure to test whether buyers' overall problem solving approach (as assessed by the suppliers) mediates the moderation effect of cost information on the relation between power and buyers' profits (H3c). The table presents the results of four regression analyses. In Step 1, the dependent variable buyer's individual profit is regressed on cost information, on power, and on the moderation term power ${ }^{*}$ cost information. In Step 2, the dependent variable problem-solving approach is first regressed on cost information, on power, and on the moderation term power ${ }^{*}$ cost information. Then, the dependent variable buyer's individual profit is regressed on cost information, on power, on the moderation term power ${ }^{*}$ cost information, and on problem solving approach. In Step 3, the dependent variable buyer's individual profit is regressed on cost information, on power, on the moderation term power ${ }^{*}$ cost information, on problem solving approach, and on the moderation term cost information problem solving approach. Regression coefficients are reported.

Table 5

Q2 Hierarchical regression results for buyer's individual profit ${ }^{\mathrm{a}}$

\begin{tabular}{|c|c|c|}
\hline & $\begin{array}{l}\text { Equation 1: situational } \\
\text { characteristics }\end{array}$ & $\begin{array}{l}\text { Equations 2: situational characteristics } \\
\text { and negotiation process }\end{array}$ \\
\hline Constant & $181.82\left({ }_{*}^{*}\right)$ & $276.58\left(\begin{array}{c}* * * \\
* * *\end{array}\right)$ \\
\hline Cost information & $825.87\left(_{*}^{* * 3}\right.$ & $488.09\left(\begin{array}{c}* * * \\
* * *\end{array}\right)$ \\
\hline Power & 516.26 & $528.19\left(^{* * *}\right)$ \\
\hline Power ${ }^{*}$ cost information & $-375.62\left(^{* *}\right)$ & -233.69 \\
\hline Information exchange & & $-467.67\left(_{* * *}^{* * *}\right)$ \\
\hline $\begin{array}{l}\text { Cost information }{ }^{*} \text { information } \\
\text { exchange }\end{array}$ & & $700.11\left(^{* * *}\right)$ \\
\hline Distributive behavior $_{*}$ & & $1188.89\left(_{* *}^{* *}\right.$ \\
\hline Power ${ }^{*}$ distributive behavior & & $-1181.94\left(^{* *}\right)$ \\
\hline$R^{2}$ & 0.41 & 0.52 \\
\hline$F$ for $R^{2}$ & $22.66\left(^{* * *}\right)$ & $14.84\left(^{* * *}\right)$ \\
\hline Change in $R^{2}$ & 0.11 & \\
\hline$F$ for change in $R^{2}$ & $5.76\left(^{* * *}\right)$ & \\
\hline
\end{tabular}

$\left({ }^{* * *}\right),\left(^{* *}\right)$, and $\left(^{*}\right)$ indicate significance levels of $1 \%, 5 \%$, and $10 \%$.

a Variable definitions in Appendix C. This table reports our results of a test for the overall mediating effects of negotiation behavior on buyer's individual profit. Although this overall test provides an interesting addition to the three-step procedures listed in Tables $2-4$, it is not sufficient in itself to demonstrate mediated moderation (Muller et al., 2005). The table presents the results of two regression analyses. First, the dependent variable buyer's individual profit is regressed on cost information, on power, and on the moderation term power ${ }^{*}$ cost information. Second, the dependent variable buyer's individual profit is regressed on cost information, on power, on the moderation term power ${ }^{*}$ cost information, on information exchange, on the moderation term cost information ${ }^{*}$ information exchange, on distributive behavior, and on the moderation term power ${ }^{*}$ distributive behavior. Regression coefficients are reported.

Weingart et al., 1996). Results for regression (1) are very similar to those obtained from the ANOVA analysis: both main effects and the moderation effect are significant. The $R^{2}$ of the model is 0.41 and the $F$-test is highly significant $(p<0.01)$. When the pro- cess variables are added to the equation, the moderation effect of cost information on the effect of power on individual profit drops to a non-significant level (coefficient $=-233.69, p>0.10$ ) and all process variables reach significance. Information 
exchange has a negative impact on individual profit (coefficient $=-467.70, \quad p<0.01$ ). However, the positive and significant moderation effect of cost information on the effect of information exchange (coefficient $=700.11, p<0.01)$ implies that this negative relation between information exchange and individual profit is only true for buyers lacking TCO information. Buyers who have access to TCO information and who exchange this information earn significantly higher individual profits. Distributive behavior has a positive effect on individual profit (coefficient $=1188.89, p<0.05$ ), but this is not the case for buyers with power (coefficient $=$ $-1181.94, p<0.05)$. In addition, the model's $R^{2}$ increases significantly, from 0.41 to 0.52 ( $F$ for change in $\left.R^{2}=5.76, p<0.01\right)$. Together, these results provide support for our expectation that the moderation effect on the outcome variable is mediated by the process variables. As shown by the significant moderation effect in equation 1 , the performance disadvantage of less powerful buyers is less pronounced when the buyer has detailed TCO information. We also expect this moderation effect to be mediated by the process variables: mediated moderation implies that the overall moderation effect is reduced once the mediating process is taken into account (Muller et al., 2005). Equation 2 clearly indicates that the moderation effect of cost information and power becomes insignificant when the process variables are added.

\section{Supplementary analyses of the supplier's negotiation outcome and behavior}

Table 1 also reports the results of the analyses of the supplier's individual profit and of the joint profit. An ANOVA on the supplier's individual profit reveals main effects for power and cost information. Suppliers facing less powerful buyers earned higher individual profits $(F(1,100)=17.46, p<0.01)$. However, supplier profits were lower when they negotiated with buyers with TCO information $(F(1,100)=15.80, p<0.01)$. Joint profits were significantly higher when the buyer possessed TCO information $(F(1,100)=15.78, p<0.01)$. Together, these results indicate that buyers with TCO information and no outside option obtained high individual profits not because they knew "how to fool" the (more powerful) suppliers, but because these dyads realized higher joint profits than dyads in which the buyer had an outside option (mean joint profit $=2446.15$ versus mean joint profit $=2336.67)$. Suppliers facing buyers without an outside option earned more than their less powerful opponents (buyer's mean individual profit $=$ 1007.69 versus supplier's mean individual profit $=$ 1438.46), reflecting the power imbalance. However, less powerful buyers with TCO information were able to earn similar individual profits as buyers with an outside option and TCO information, a result that we explained through the detailed analysis of the buyers' negotiation behavior.

Finally, in order to assess the effects of buyers' behavior on suppliers' behavior, we present results (not tabulated) on the suppliers' bargaining behavior. Recall that the experimental manipulation for the suppliers was the same in each of the experimental conditions: suppliers always had an outside option and full cost information. Accordingly, the differences in suppliers' bargaining behavior across the different experimental cells can be explained by their interaction with buyers. An ANOVA on the suppliers' information exchange shows a main effect for cost information $(F(1,100)=6.92, p<0.01)$ : suppliers facing buyers with TCO information disclosed more information than suppliers facing buyers with traditional information. We find no effect of the manipulations with respect to the buyers' conditions on the suppliers' integrative behavior, nor on the number of explicit requests for cooperation issued by suppliers. Furthermore, we observe that suppliers facing a powerful buyer used distributive behavior more frequently than suppliers in the other experimental conditions $(F(1,100)=0.58, p<0.10)$. More specifically, we find that suppliers facing a powerful buyer with TCO information used more distributive threats and referred to their outside option more often than suppliers in the other experimental conditions. Suppliers' negotiation behavior is also assessed by the composite measure problem solving approach (based on the post-bargaining questionnaires of the buyers). Main effects are found for cost information $(F(1,100)=4.83$, $p<0.05)$ and power $(F(1,100)=3.18, p<0.10)$. Thus, compared to buyers with traditional cost information, buyers with TCO information reported that suppliers used more problem solving techniques and fewer distributive bargaining techniques. Furthermore, less powerful buyers felt that their opponent employed more problem solving techniques than buyers with an outside option. Overall, these results provide evidence that buyers' behavior strongly affects suppliers' behavior. 


\section{Discussion and conclusion}

In this paper, we examine the moderation effect of cost information (TCO information versus traditional cost information) on a buyer's individual profit at both high and low levels of buyer power. Our results indicate that the availability of detailed TCO information may alleviate the disadvantage that dependent buyers face vis-à-vis a more powerful supplier. This finding has important managerial implications. On the one hand, it implies that less powerful buyers can compensate for their power disadvantage by gathering more detailed cost information. On the other hand, powerful buyers do not seem to be able to use this more detailed cost information to enhance their power advantage in order to obtain even higher individual profits.

We explore the driver behind this result by examining the negotiation process. Consistent with exchange theory and recent literature on information processing, we expect that buyers with detailed cost information and less power than their opponent try to (re)gain control over their own outcomes by sharing information in an effort to create integrative solutions. Because of their higher epistemic motivation, less powerful buyers have a greater incentive to engage in information acquisition and processing (e.g., Fiske, 1993; Van Kleef et al., 2006). Accordingly, we expect that less powerful buyers with TCO information seek a more integrative bargaining situation than powerful buyers, who are more prone to using distributive bargaining techniques because of their low epistemic motivation (e.g., De Dreu \& Van Kleef, 2004; Fiske, 1993; Weingart et al., 1996).

Support for these conjectures is found in our follow-up analyses, in which we examine whether the moderation effect of TCO information on the relation between power and individual profit can be explained by the choice of negotiation strategy. Using Baron and Kenny's (1986) framework for combining mediation and moderation, we find that the moderation effect of cost information on the relation between power and individual profit is mediated by buyers' bargaining behavior. Analysis of the buyers' communications suggests that buyers with TCO information disclose more information than buyers with traditional cost information. Consistent with prior research (e.g., Perdue \& Summer, 1991), we find that more powerful buyers disclose less information and use more distributive bargaining techniques than less powerful buyers. The results also reveal an unexpected positive effect of TCO information on distributive behavior. However, this effect can be explained by the finding that buyers with TCO information and power tend to use distributive techniques. Furthermore, a limited analysis of suppliers' bargaining behavior revealed its reciprocal nature. Suppliers facing buyers with TCO information disclosed more information than suppliers facing buyers with traditional information. It also emerged that suppliers facing powerful buyers with TCO information used more distributive bargaining techniques than suppliers in the other experimental conditions. As the experimental manipulation for the suppliers is the same in each of the experimental conditions, the differences in suppliers' bargaining behavior across the different experimental cells can only be explained by their interaction with the buyers. These findings provide support for our conjecture that less powerful buyers are able to create a cooperative relationship, into which the supplier is willing to enter. This resulted not only in higher individual profits, but also in higher joint profits.

From these results, we conclude that the manipulation of power and cost information resulted in buyers using different negotiation techniques. Less powerful buyers who have access to TCO data are more likely to resort to problem solving techniques, whereas powerful buyers tend to rely on distributive bargaining techniques. Particularly interesting is that the problem solving strategy adopted by less powerful buyers with TCO information seems to be effective, whereas the distributive bargaining strategy adopted by more powerful buyers with TCO results in less information sharing and in less effective negotiation outcomes. Less powerful buyers seem to be motivated to create a cooperative and coordinated relationship, in which the supplier is willing to consider the buyer's objectives. When a buyer shares information about needs and preferences and/or makes concessions that facilitate the development of a solution, the supplier is likely to reciprocate (e.g., Campbell et al., 1998; Dekker, 2004). This may explain the higher individual profits for less powerful buyers with TCO information. Less powerful buyers lacking TCO information are less able or willing to communicate the right information and therefore to create integrative situations. More powerful buyers, on the other hand, believe to have power and choose a distributive bargaining strategy that, in a tit-for-tat move, the supplier responds to by also resorting to a distributive 
bargaining strategy. Thus, a powerful buyer's distributive bargaining strategy may not be effective when he is facing an equally powerful supplier.

Overall, our results suggest that powerful buyers with refined TCO information may not maximize possible benefits from buyer-supplier interactions due to their bargaining strategy. Their (false) feeling of power causes an increase in distributive bargaining techniques and a reluctance to share the information necessary for interfirm cost minimization. This implies that powerful buyers may only benefit from more refined accounting information systems if these firms undertake efforts that encourage information sharing and discourage distributive bargaining strategies. Future research should examine whether, and under what conditions, interfirm control systems and incentive systems may motivate buyers and suppliers to share cost information in such a way that supply chain performance is improved.

We conclude with remarks on several limitations of this study and further directions for future research. First, while the experimental context induced by a simple negotiation game allows us to maintain control over exogenous variables, the scope for generalizing the results is somewhat limited. Other factors, such as the incentive system, past negotiation history, and future negotiation probabilities, have been shown to impact negotiated outcomes but are not included in the present analysis. Future research is needed to determine the sensitivity of our results to several parameters excluded in the current study.

Second, this study manipulates the experimental conditions of the buyers, but not the suppliers, that is, the suppliers' experimental conditions were held constant. In particular, suppliers were always fully informed and powerful. As a consequence, our conclusions do not generalize beyond negotiation settings in which the supplier is always at least as powerful as the buyer. Further research can modify these experimental conditions and examine the role of TCO information from both buyer and supplier perspectives.

Third, although optimal joint outcomes are introduced, our study focuses primarily on buyer outcomes. This focus underplays the cost/benefit trade-off of obtaining the additional information needed for TCO. Since TCO information is not costless, it would be interesting to consider whether buyers would be willing to incur the cost of obtaining TCO information if it is efficient to do so.
Fourth, our manipulation of TCO information is obviously a simplification of reality, providing many avenues for further research. In this paper, we take a deterministic approach to TCO information, which allows us to study the impact of cost information on negotiation behavior and outcomes. Our aim was not to describe a value chain and ABC analysis, nor to discuss data collection mechanisms and challenges. Neither did we seek to identify and categorize important TCO cost drivers. However, more research is needed on these issues to effectively identify critical cost drivers for estimating TCO. Future research may consider aspects such as the manner in which buyers collect TCO data (e.g., from the supplier, benchmarking, past experience), the type of TCO systems implemented (e.g., formal vs. informal, standardized vs. unique models), and how these design aspects impact buyer-supplier relations and negotiations. In addition, examining the effects of imperfect TCO information would also be interesting. In this study, perfect TCO information was provided to decision-makers. In reality, TCO information is characterized by mistakes and simplifications, which may have important implications on the negotiation process and its outcomes. Similarly, it would be interesting to consider how costs that are difficult to measure (e.g., opportunity costs of reduced sales, productivity losses due to downtime) can be included in TCO systems. Because of the difficulty of measuring these costs reliably, they are typically not recorded in a buyer's accounting system. However, they may represent a substantial cost in total costs. An investigation of how the negotiation process and outcomes are affected when less objective or less reliable cost estimates are explicitly included in the TCO system would add useful insights to the literature. Finally, further research could consider whether audited TCO information (either by a third party or by the partner) would be considered more reliable than unaudited TCO information, and if so, what the implications for the buyer-supplier relation would be.

\section{Acknowledgements}

The comments of Shannon Anderson, Eddy Cardinaels, Henri Dekker, Luc Sels, the participants at the BAA conference in Edinburgh, the EAA conference in Gothenburg, the AOS-Bocconi conference in Milan, the AAA conference in Clearwater Beach, and two anonymous reviewers are gratefully 
acknowledged, as is the research funding provided by the Fund for Scientific Research - Flanders (Project G.0261.00) and by the National Bank of Belgium (Project NB/05/01).
Appendix A. Experimental cells and corresponding cost tables
1336

1337

1338

Power

Low power (no outside option)

Equal power (outside option)

Cost information

TCO information

Cell $1(n=30)$

Cell $2(n=26)$

Traditional cost information

Cell $3(n=26)$

Cell $4(n=22)$

\begin{tabular}{|c|c|c|c|c|c|}
\hline Price (=income) & \multicolumn{2}{|r|}{ Maintenance } & \multicolumn{3}{|c|}{ Spare parts } \\
\hline Cost table for th & lier (ir & 3 and 4$)^{\mathrm{a}}$ & & & \\
\hline Contract 1 & 600 & Contract $\mathrm{A}^{*}$ & 1350 & Contract $\mathrm{R}$ & 2250 \\
\hline Contract 2 & 1200 & Contract B & 1200 & Contract S & 2000 \\
\hline Contract 3 & 1800 & Contract $\mathrm{C}$ & 1050 & Contract $\mathrm{T}$ & 1750 \\
\hline Contract 4 & 2400 & Contract D & 900 & Contract U & 1500 \\
\hline Contract $5^{*}$ & 3000 & Contract E & 750 & Contract V & 1250 \\
\hline Contract 6 & 3600 & Contract $\mathrm{F}$ & 600 & Contract W & 1000 \\
\hline Contract 7 & 4200 & Contract $\mathrm{G}$ & 450 & Contract X & 750 \\
\hline Contract 8 & 4800 & Contract $\mathrm{H}$ & 300 & Contract Y & 500 \\
\hline Contract 9 & 5400 & Contract I & 150 & Contract $Z^{*}$ & 250 \\
\hline
\end{tabular}

Income $=6000$

Price $(=\mathrm{cost})$

Cost table for the buyer with TCO information (in cell 1 and 2):

Contract 1

Contract 2

Contract 3

Contract 4

Contract $5^{*}$

Contract 6

Contract 7

Contract 8

Contract 9
600

1200

1800

2400

3000

3600

4200

4800

5400
Contract A*

Contract B

Contract $\mathrm{C}$

Contract D

Contract E

Contract $F$

Contract $\mathrm{G}$

Contract $\mathrm{H}$

Contract I
Spare parts

Contract $\mathrm{R}$

150

Contract $\mathrm{S}$

300

Contract T

Contract U

450

Contract V

600

1000

Contract W

750

1500

1750

Contract X

900

Contract Y

1050

2000

Contract $Z^{*}$

Income $=6000$

Price $(=\mathrm{cost})$

Maintenance $^{\mathrm{a}}$

Cost table for the buyer with traditional cost information (in cell 3 and 4 ):

Contract 1

Contract 2

Contract 3

Contract 4

\section{0}

1200

1800

2400
Contract $\mathrm{A}^{*}$

Contract B

Contract $\mathrm{C}$

Contract D
1

2

3

4

Spare parts ${ }^{\mathrm{b}}$

Contract R 3

Contract $\mathrm{S}$

Contract T

Contract U

(continued on next page)

Please cite this article in press as: Van den Abbeele, A. et al., The effect of cost information on buyer-supplier negotiations ..., Accounting, Organizations and Society (2008), doi:10.1016/j.aos.2008.05.005 


\begin{tabular}{|c|c|c|c|c|c|}
\hline Contract $5^{*}$ & 3000 & Contract E & 5 & Contract V & $\overline{15}$ \\
\hline Contract 6 & 3600 & Contract F & 6 & Contract W & 18 \\
\hline Contract 7 & 4200 & Contract $\mathrm{G}$ & 7 & Contract X & 21 \\
\hline Contract 8 & 4800 & Contract $\mathrm{H}$ & 8 & Contract Y & 24 \\
\hline Contract 9 & 5400 & Contract I & 9 & Contract $Z^{*}$ & 27 \\
\hline
\end{tabular}

${ }^{a}$ Number of maintenance sessions performed by the buyer each month.

b Spare parts procured by the buyer from a third party each month.

\section{Appendix B. Measuring negotiation behavior}

\section{B.1. Behavioral coding categories}

\begin{tabular}{ll}
\hline Category & Examples \\
\hline $\begin{array}{l}\text { Information } \\
\text { exchange }\end{array}$ & - Maintenance is more expensive for my company than spare parts \\
Rewards & Maintenance contracts start at $€ 250(=$ contract $A)$ and increase by $€ 250$ until $€ 2250(=$ contract I $)$; con- \\
tracts for spare parts start at $€ 150(=$ contract $R)$ and increase by $€ 150$ until $€ 1350(=$ contract $Z)$ \\
$\begin{array}{l}\text { Positive normative } \\
\text { appeals }\end{array}$ & - I am pleased with the concessions made thus far \\
Request for & Your offers have been fair and equitable \\
cooperation & - Let us cooperate \\
General threats & - Make a concession or you will be in trouble \\
Exit threats & - Respond with a concession or I will call another supplier \\
Punishment & - This negotiation is going nowhere \\
Warnings & - My company has a policy against uncooperative suppliers \\
Positional & - I refuse to concede any further \\
commitment & - I refuse to drop my price below the present level \\
\hline
\end{tabular}

\section{B.2. Buyers' problem solving approach}

Observed ratings from suppliers' questionnaires (items were reverse coded)

Do you feel that the person with whom you were paired was more interested in solving your mutual problem, or more self-interested? 1

Solving a mutual problem

Rate your partner's bargaining strategies on the following scales: 1

Accommodating 1

Honest

1

Information sharing $\begin{array}{llll}2 & 3 & 4 & 5\end{array}$

\section{Self-interested}

$\begin{array}{llll}2 & 3 & 4\end{array}$

$\begin{array}{llll}2 & 3 & 4 & 5\end{array}$

$2 \quad 3 \quad 4 \quad 5$

\section{Deceptive}

Withholding information 
Appendix C. Bivariate correlation matrix $(n=104)$

\begin{tabular}{|c|c|c|c|c|c|c|c|c|c|c|c|}
\hline & & 1 & 2 & 3 & 4 & 5 & 6 & 7 & 8 & 9 & 10 \\
\hline 1 & Buyer's individual profit ${ }^{\mathrm{a}}$ & 1 & & & & & & & & & \\
\hline 2 & Supplier's individual profit & $-0.71\left(\begin{array}{l}* * \\
* *\end{array}\right)$ & 1 & & & & & & & & \\
\hline 3 & Joint profit ${ }^{\mathrm{c}}$ & $0.54\left(^{* *}\right)$ & $0.21\left(^{*}\right)$ & 1 & & & & & & & \\
\hline 4 & Information exchange $^{\mathrm{d}}$ & 0.14 & 0.19 & $0.41\left(^{* *}\right)$ & 1 & & & & & & \\
\hline 5 & Integrative behavior ${ }^{\mathrm{e}}$ & 0.06 & -0.02 & 0.05 & 0.02 & 1 & & & & & \\
\hline 6 & Requests for cooperation ${ }^{\mathrm{f}}$ & 0.15 & 0.05 & $0.27\left(^{* *}\right)$ & $0.30\left(^{* *}\right)$ & $0.36\left(^{* *}\right)$ & 1 & & & & \\
\hline 7 & Distributive behavior ${ }^{\mathrm{g}}$ & $0.22\left(^{*}\right)$ & $-0.20\left(^{*}\right)$ & 0.07 & 0.09 & -0.11 & -0.11 & 1 & & & \\
\hline 8 & Problem solving approach ${ }^{\mathrm{h}}$ & $0.41\left(\begin{array}{c}* * \\
* *\end{array}\right)$ & -0.10 & $0.44\left(\begin{array}{l}* * \\
* *\end{array}\right)$ & $0.35\left(\begin{array}{l}* * \\
*\end{array}\right)$ & 0.16 & $0.38\left(\begin{array}{l}* * \\
* *\end{array}\right)$ & $0.09 *$ & $1 \quad * *$ & & \\
\hline 9 & Cost information ${ }^{\mathrm{i}}$ & $0.55(* *)$ & $-0.34\left(\begin{array}{c}* * \\
* *\end{array}\right)$ & $0.36\left(^{* *}\right)$ & $0.23\left(\begin{array}{c}* \\
*\end{array}\right)$ & 0.13 & $0.23\left({ }^{* *}\right)$ & $0.23(*)$ & $0.82\left(\begin{array}{c}* * \\
*\end{array}\right)$ & 1 & \\
\hline 10 & Power $^{\mathrm{j}}$ & $0.27\left(^{* *}\right)$ & $-0.35\left(^{* *}\right)$ & -0.04 & $-0.20\left(^{*}\right)$ & $-0.21\left(^{*}\right)$ & $-0.25\left(^{* *}\right)$ & $0.35\left(^{* *}\right)$ & $-0.23\left(^{*}\right)$ & 0.00 & 1 \\
\hline
\end{tabular}

${ }^{*}$ ) Correlation is significant at the 0.05 level (2-tailed).

${ }^{* *}$ ) Correlation is significant at the 0.01 level (2-tailed).

a Buyer's individual profit at the end of the game (based on the cost table provided in Appendix A).

b Supplier's individual profit at the end of the game (based on the cost table provided in Appendix A)

c Joint profit is the sum of buyer's individual profit and supplier's individual profit at the end of the game.

"Information exchange is coded " 0 " for participants not revealing any information about their cost structure, " 1 " for participants revealing the relative importance (but not the numerical values) of each of the three issues under negotiation, and " 2 " for participants revealing the relative importance and the numerical values of each of the three issues under negotiation.

${ }^{\mathrm{e}}$ Coded from the messages sent by buyers (based on the behavioral coding scheme in Appendix B1). Summated scale determined by adding up two integrative behavior types (rewards and positive normative appeals) and solving for the mean value. Cronbach's alpha $=0.70$

${ }^{\mathrm{f}}$ Coded from the messages sent by buyers (based on the behavioral coding scheme in Appendix B1). Single scale item (requests for cooperation).

g Coded from the messages sent by buyers (based on the behavioral coding scheme in Appendix B1). Summated scale determined by adding five distributive behavior types (general threats, exit threats, positional commitment, punishments, warnings) together and solving for the mean value. Cronbach's alpha $=0.81$.

${ }^{\mathrm{h}}$ Buyer's problem solving approach based on observed ratings from supplier's questionnaire. Summated scale determined by adding the four post-bargaining questionnaire items included in Appendix B2 together and solving for the mean value. Cronbach's alpha $=0.88$.

Dummy variable, experimental manipulation: 0 for traditional cost information, 1 for TCO information.

${ }^{\mathrm{j}}$ Dummy variable, experimental manipulation: 0 for buyers with no outside option, 1 for buyers with an outside option. 


\section{References}

1340 213-238. 279-314. 1-23. 27-49. 22-30.
Anderson, S. W., \& Dekker, H. C. (2005). Management control for market transactions: The relation between transaction characteristics, incomplete contract design and subsequent performance. Management Science, 51, 1734-1752.

Baiman, S., \& Rajan, M. V. (2002). Incentive issues in inter-firm relationships. Accounting, Organizations and Society, 27,

Bame-Aldred, C. W., \& Kida, T. (2007). A comparison of auditor and client initial negotiation positions and tactics. Accounting, Organizations and Society, 32, 497-511.

Baron, R., \& Kenny, D. (1986). The moderator-mediator variable distinction in social psychological research: Conceptual, strategic, and statistical considerations. Journal of Personality and Social Psychology, 51, 1173-1182.

Bazerman, M. H., Curhan, J. R., Moore, D. A., \& Valley, K. L. (2000). Negotiation. Annual Review of Psychology, 51,

Bottom, W. P., Holloway, J., Miller, G. J., Mislin, A., \& Whitford, A. (2006). Building a pathway to cooperation: Negotiation and social exchange between principal and agent. Administrative Science Quarterly, 51, 29-58.

Campbell, N. C. G., Graham, J. L., Jolibert, A., \& Meissner, H. G. (1998). Marketing negotiations in France, Germany, the United Kingdom, and the United States. Journal of Marketing, 52, 49-62.

Carr, L. P., \& Ittner, C. D. (1992). Measuring the cost of ownership. Journal of Cost Management, 6, 7-13.

Craft, J. A. (1981). Information disclosure and the role of the accountant in collective bargaining. Accounting, Organizations and Society, 6, 97-107.

De Dreu, C. K. W., Beersma, B., Stroebe, K., \& Euwema, M. C. (2006). Motivated information processing, strategic choice, and the quality of negotiated agreement. Journal of Personality and Social Psychology, 90, 927-943.

De Dreu, C. K. W., \& Carnevale, P. (2003). Motivational bases of information processing and strategy in conflict and negotiation. Advances in Experimental Social Psychology, 35, 235-291.

De Dreu, C. K. W., \& Van Kleef, G. A. (2004). The influence of power on the information search, impression formation, and demands in negotiation. Journal of Experimental Social Psychology, 40, 303-319.

Degraeve, Z., \& Roodhooft, F. (1999). Effectively selecting suppliers using total cost of ownership. Journal of Supply Chain Management, 35, 5-10.

Dekker, H. C. (2003). Value chain analysis in interfirm relationships: A field study. Management Accounting Research, 14,

Dekker, H. C. (2004). Control of inter-organizational relationships: Evidence on appropriation concerns and coordination requirements. Accounting, Organizations and Society, 29,

Drake, A., \& Haka, S. (2008). Does ABC exacerbate the hold-up problem between buyers and suppliers?. The Accounting Review 83, 29-60.

Ellram, L. M. (1995). Activity based costing and total cost of ownership: A critical linkage. Journal of Cost Management, 9,

Emerson, R. M. (1976). Social exchange theory. Annual Review of Sociology, 2, 335-362.
Fisher, J., Frederickson, J. R., \& Peffer, S. A. (2000). Budgeting An experimental investigation of the effects of negotiation. The Accounting Review, 75, 93-114.

Fisher, J., Frederickson, J. R., \& Peffer, S. A. (2006). Budget negotiations in multi-period settings. Accounting, Organizations and Society, 31, 511-528.

Fiske, S. T. (1993). Controlling other people: The impact of power on stereotyping. American Psychologist, 48, 621-628.

Gelfand, M., \& Christakopoulou, S. (1999). Culture and negotiation cognition: Judgment accuracy and negotiation processes in individualistic and collectivistic cultures. Organizational Behavior and Human Decision Processes, 79, 248-269.

Gibbins, M., McCracken, S. A., \& Salterio, S. E. (2005). Negotiations over accounting issues: The congruency of audit partner and chief financial officer recalls. Auditing: A Journal of Practice and Theory, 24, 171-193.

Gibbins, M., Salterio, S. E., \& Webb, A. (2001). Evidence about auditor-client management negotiation concerning client's financial reporting. Journal of Accounting Research, 39, $553-563$.

Giebels, E., De Dreu, C. K. W., \& Van de Vliert, E. (2000). Interdependence in negotiation: Effects of exit options and social motive on distributive and integrative negotiation. European Journal of Social Psychology, 30, 255-272.

Goodwin, S. A., Gubin, A., Fiske, S. T., \& Yzerbyt, V. Y. (2000). Power can bias impression processes: Stereotyping subordinates by default and by design. Group Processes and Intergroup Relations, 3, 227-256.

Ittner, C. D., Larcker, D. F., \& Meyer, M. W. (2003). Subjectivity and the weighting of performance measures: Evidence from the balanced scorecard. The Accounting Review, 78, 725-758.

Kachelmeier, S. J., \& Towry, K. L. (2002). Negotiated transfer pricing: Is fairness easier said than done?. The Accounting Review 77, 571-593.

Kadous, K., Koonce, L., \& Towry, K. L. (2005). Quantification and persuasion in managerial judgment. Contemporary Accounting Research, 22, 643-686.

Kelley, H. H. (1966). A classroom study of the dilemmas in interpersonal negotiation. In K. Archibald (Ed.), Strategic interaction and conflict. Berkerley, California: Institute of International Studies.

Kelley, H. H., \& Thibaut, J. (1978). Interpersonal relations: A theory of interdependence. New York: Wiley.

Keltner, D., Gruenfeld, D. H., \& Anderson, C. (2003). Power, approach, and inhibition. Psychological Review, 110, 265-284.

Kersten, G. (2001). Modeling distributive and integrative negotiations: Reviewed and revised characterization. Group Decision and Negotiation, 10, 493-514.

Luft, J., \& Libby, R. (1997). Profit comparisons, market prices and managers' judgments about negotiated transfer prices. The Accounting Review, 72, 217-229.

Luft, J., \& Shields, M. D. (2003). Mapping management accounting: Graphics and guidelines for theory-consistent empirical research. Accounting, Organizations and Society, 28, 169-249.

Muller, D., Judd, C. M., \& Yzerbyt, V. Y. (2005). When moderation is mediated and mediation is moderated. Journal of Personality and Social Psychology, 89, 852-863.

Murnigham, J., \& Bazerman, M. (1990). A perspective on negotiation research in accounting and auditing. The Accounting Review, 65, 642-657.
1400

1401

1402

1403

1404

1405

1406

1407

1408

1409

1410

1411

1412

1413

1414

1415

1416

1417

1418

1419

1420

1421

1422

1423

1424

1425

1426

1427

1428

1429

1430

1431

1432

1433

1434

1435

1436

1437

1438

1439

1440

1441

1442

1443

1444

1445

1446

1447

1448

1449

1450

1451

1452

1453

1454

1455

1456

1457

1458

1459

1460

1461 
Ng, T. B-P., \& Tan, H-T. (2003). Effects of authoritative guidance availability and audit committee effectiveness on auditors' judgment in an auditor-client negotiation context. The Accounting Review, 78, 801-818.

Northcraft, G. B., \& Neale, M. A. (1986). Opportunity costs and the framing of resource allocation decisions. Organizational Behavior and Human Decision Processes, 37, 348-356.

Perdue, B. C., \& Summer, J. O. (1991). Purchasing agents' use of negotiation strategies. Journal of Marketing Research, 28, 175-189.

Pinkley, R. L., Neale, M. A., \& Bennett, R. J. (1994). The impact of alternatives to settlement in dyadic negotiation. Organizational Behavior and Human Decision Processes, 57, 97-116.

Porter, M. E. (1985). Competitive advantage: Creating and sustaining superior performance. New York: The Free Press.

Putman, L. L., \& Fairhurst, G. T. (2001). Discourse analysis in organization. In F. Jablin \& L. Putman (Eds.), The New Handbook of Organizational Communication. Thousand Oaks, CA: Sage.

Roodhooft, F., Hiel, G., Van den Abbeele, A., \& van Doveren, B. (2003). Optimised sourcing strategies using total cost of ownership. Cost Management, 17, 28-35.

Roodhooft, F., Van den Abbeele, A., \& Peeters, F. (2005). Calculating the total cost of ownership of utilities: A case of inter-firm cost management. Cost Management, 19, 1323.

Shank, J. K. (1989). Strategic cost management: New wine, or just new bottles?. Management Accounting Research 1, 47-65.

Shank, J. K., \& Govindarajan, V. (1992). Strategic cost management: The value chain perspective. Journal of Management Accounting Research, 4, 179-197.
Thibaut, J. W., \& Kelley, H. H. (1959). The social psychology of groups. NY: John Wiley \& Sons.

Tomkins, C. (2001). Interdependencies, trust and information in relationships, alliances and networks. Accounting, Organizations and Society, 26, 161-191.

Van Kleef, G. A., De Dreu, C. W., Pietroni, D., \& Manstead, A. S. R. (2006). Power and emotion in negotiation: Power moderates the interpersonal effects of anger and happiness and concession making. European Journal of Social Psychology, 36, 557-581.

Walton, R. E., \& McKersie, R. B. (1966). Behavioral dilemmas in mixed-motive decision making. Behavioral Science, 11, 370-384.

Waterhouse, J., Gibbins, M., \& Richardson, A. J. (1993). Strategic financial disclosure: Evidence from labor negotiations. Contemporary Accounting Research, 9, 526-550.

Weingart, L. R., Hyder, E. B., \& Prietula, M. J. (1996). Knowledge matters: The effect of tactical descriptions on negotiation behavior and outcome. Journal of Personality and Social Psychology, 70, 1204-1217.

Windsor, C. A., \& Ashkanasy, N. M. (1995). The effect of client management bargaining power, moral reasoning development, and belief in a just world on auditor independence. Accounting, Organizations and Society, 20, 701-720.

Wolfe, R., \& McGinn, K. L. (2005). Perceived, relative power and its influence on negotiations. Group Decisions and Negotiation, 14, 3-20.

Wouters, M., Anderson, J. C., \& Wynstra, F. (2005). The adoption of total cost of ownership for sourcing decisions - A structural equations analysis. Accounting, Organizations and Society, 30, 167-191.
1493

1494

1495

1496

1497

1498

1499

1500

1501

1502

1503

1504

1505

1506

1507

1508

1509

1510

1511

1512

1513

1514

1515

1516

1517

1518

1519

1520

1521

1522

1523

1524 